\title{
Jakie dzielnice? Dylematy narodzin krakowskiego samorządu 1989-1991
}

\#Kraków \#rozwój terytorialny w XIX i XX wieku \#dzielnice \#podział administracyjny \#samorząd \#decentralizacja \#Kraków \#territorial government in the 19th and 20th century \#districts \#administrative division \#self-government

U schyłku I Rzeczypospolitej - w wyniku przyjętych w 1791 roku przez Sejm Wielki dwóch doniosłych ustaw o miastach królewskich - podjęto proces administracyjnego scalenia średniowiecznego trójmiasta wraz z otaczającymi je jurydykami. Był to równocześnie koniec nadanego Krakowowi w roku 1257 systemu magdeburskiego i „wyjście” miasta extra muros. Kolejne podziały Krakowa na dzielnice, ich kształt i kompetencje, były nie tylko funkcją ekspansji terytorialnej miasta, ale zostały też w dużej mierze zdeterminowane przez zmieniające się w ciągu XIX i XX wieku systemy polityczne. Nowy podział administracyjny Krakowa stał się w roku 1990 jedną z fundamentalnych kwestii w toczącej się wówczas gorącej debacie o przyszłości miasta i o kształcie odradzającego się nad Wisłą samorządu. Była to wówczas z wielu powodów kwestia precedensowa w skali Polski.

At the end of the First Polish Republic, the process of administrative unification of the medieval tripolis with the surrounding jurydyki was started, after the passing of two significant acts on royal towns, which were enacted in 1791 by the Sejm Wielki. This meant the end of the Magdeburg system granted to Kraków in 1257, and the extra muros expansion of the city. The further divisions of Krakow into districts (dzielnice), their form and competences, were not only a function of the territorial expansion of the city, but they were also determined to a great extent by the political systems changing throughout the 19th and 20th century. In 1990 the new administrative division of Kraków became one of the fundamental questions in the heated debate, ongoing then, about the future of the city and the form of the self-government being restored on the Vistula River. For many reasons, it was a precedential question on the country scale at the time.

Miasto. Pamięć i Przyszłość 1 (2017) ISSN 2543-621X

\section{OPEN ACCESS}

Citation: Purchla J., What districts? Dilemmas around the birth of Kraków self-government of 1989-1991, „Miasto. Pamięć i Przyszłość: Wrocławski Rocznik Samorządowy" - No 1,

https://doi.org/10.xxxxx

Editor: Katarzyna Uczkiewicz

Received: October, 2016

Accepted: December, 2016

Published: December, 2016

Copyright: @ Ośrodek „Pamięć i Przyszłość" This is an open access article distributed under the terms of the Creative Commons Attribution-ShareAlike Licence, which permits unrestricted use, distribution, and reproduction in any medium, provided the original author and source are credited, with indications if any changes are made. All derivative works must be licensed under the same licence.

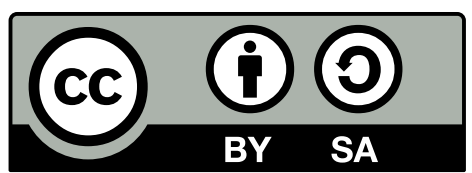




\section{Jakie dzielnice? Dylematy narodzin krakowskiego samorządu 1989-1991}

Nie ulega wątpliwości, że dopiero samorząd ostatecznie przełamał w roku 1990 w Polsce syndrom państwa komunistycznego. Widoczne było to zwłaszcza w takich miastach jak Kraków, które odzyskiwały podmiotowość po dziesięcioleciach ubezwłasnowolnienia. Równocześnie przypadek Krakowa roku 1990 okazać miał się szczególnie pouczającym rozdziałem w historii polskiej rewolucji demokratycznej. Bo demokracja szybko ujawniła niejednorodność czy raczej złożoność Krakowa. Przez 40 lat PRL-u miasto szybko się rozrastało. Nie było jednak żadnego mechanizmu, który by wówczas weryfikował postawy i przekonania obywateli. Dlatego jedną z fundamentalnych kwestii w naszej debacie o Krakowie i samorządzie w roku 1990 stała się kwestia nowego podziału administracyjnego miasta i upodmiotowienia jego mieszkańców.

Wiosną roku 1990 Kraków w sensie prawno-ustrojowym nie istniał jako miasto! Był od reformy administracyjnej roku 1975 - obok Warszawy i Łodzi - jednym z trzech tzw. województw miejskich. Prezydent Krakowa - przed reformą samorządową roku 1990 - był de facto wojewodą wykonującym w imieniu rządu scentralizowaną władzę zarówno na terenie miasta (podzielonego wówczas na cztery duże dzielnice liczące po około 200 tys. mieszkańców każda), jak i terytorium w promieniu około 40 km od centrum aglomeracji (podzielonego na ponad 40 gmin wiejskich i miejskich). Wydzielenie Krakowa jako nowej gminy miejskiej powstałej 27 maja 1990 r. - od reszty województwa; rozdzielenie funkcji dotychczasowego prezydenta-wojewody od nowej funkcji prezydenta rozumianego jako burmistrz wielkiego miasta; wreszcie wydzielenie z jednego wielkiego urzędu terenowego organu administracji państwowej (jakim był urząd wojewódzki) urzędu miasta Krakowa i stworzenie zupełnie nowego systemu dzielnic - jako jednostek pomocniczych - to były nadzwyczajne zadania, których realizacja rozpoczęła się w Krakowie dopiero w czerwcu 1990 r., tzn. już po wyborach. Takiej kumulacji problemów natury 


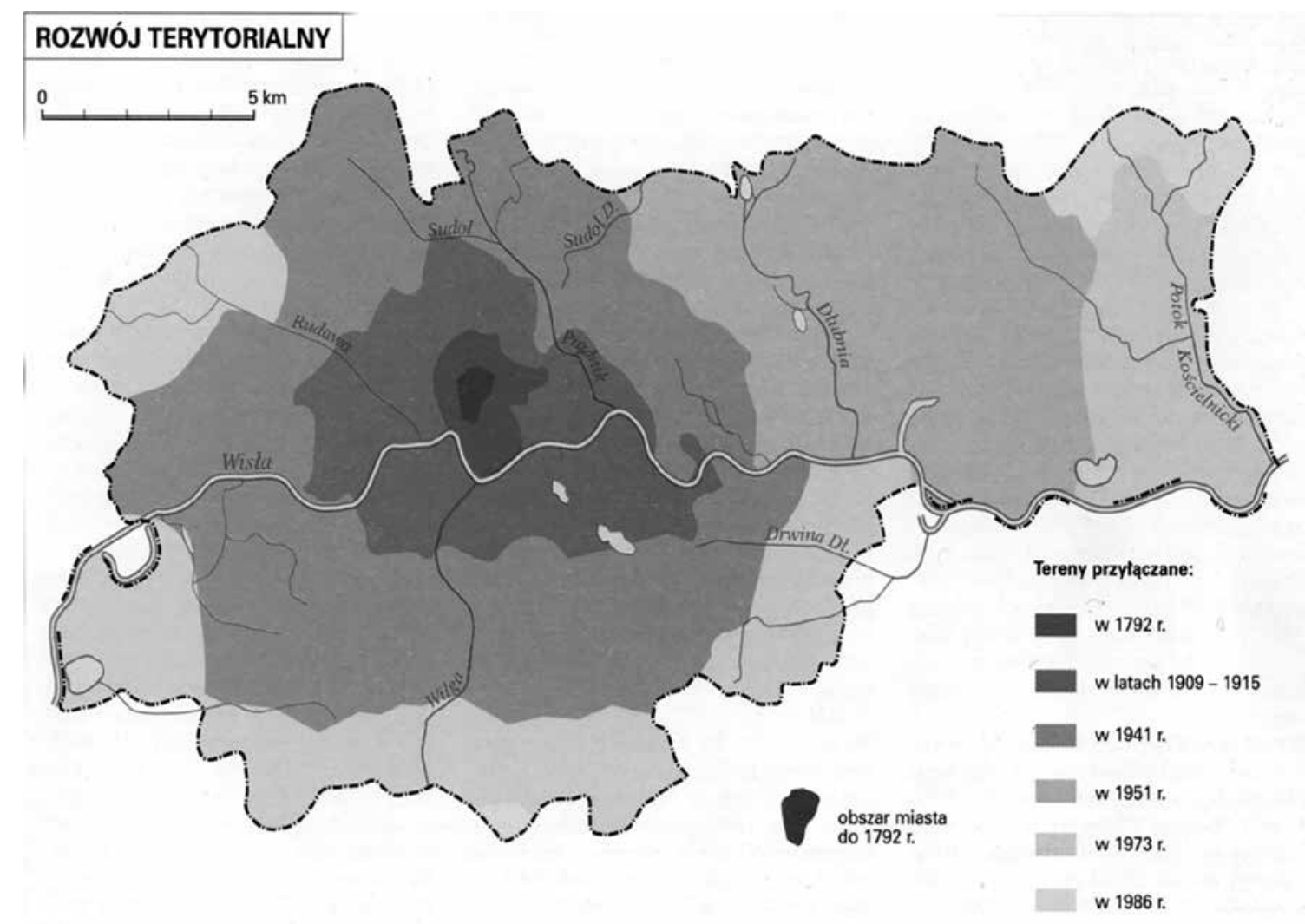

Rozwój terytorialny Krakowa. Wg Encyklopedia Krakowa. A.H. Stachowski [red.], Warszawa-Kraków 2000.

strukturalnej nie miało wówczas żadne polskie miasto. Tak np. w Gdańsku, Poznaniu czy Wrocławiu urzędy wojewódzkie i urzędy miejskie były wyraźnie rozdzielone w poprzednim systemie administracyjnym, natomiast $w$ analogicznych do Krakowa województwach miejskich: Warszawie $i$ Łodzi prezydenci-wojewodowie z mandatu "Solidarności" objęli władzę już wcześniej (odpowiednio w styczniu i lutym 1990 r.) - mieli więc czas na przeprowadzenie tych skomplikowanych

1. Szerzej na ten temat: J. Purchla, Powrót do miasta - trudne narodziny samorzadu w Krakowie w roku 1990, [w:] Kraków - metropolia. W 25. rocznice narodzin samorzadu terytorialnego w III Rzeczpospolitej, red. J. Purchla, Kraków 2016, s.109-116; Por. też: J. Purchla, 25-lecie krakowskiego samorzadu, [w:] 25 lat odrodzonego samorzadu Krakowa, Kraków 2016, s.6-13; operacji jeszcze przed wyborami 27 maja, przygotowując dla nowego samorządu aparat dla wykonywania władzy'. Ustawa samorządowa napisana dla potrzeb gminy przeciętnej wielkości tej specyfiki i złożoności Krakowa w roku 1990 nie uwzględniała.

Debata nad kształtem samorządu i nowym kształtem miasta toczyła się już od jesieni roku 1989 na forum Krakowskiego Komitetu Obywatelskiego „Solidarność" i zawiązanego wówczas Zespołu Ekspertów "Kraków” równolegle do prowadzonych w Sejmie kontraktowym prac

Miasto. Pamięć i Przyszłość 1 (2016) ISSN 2543-621X 


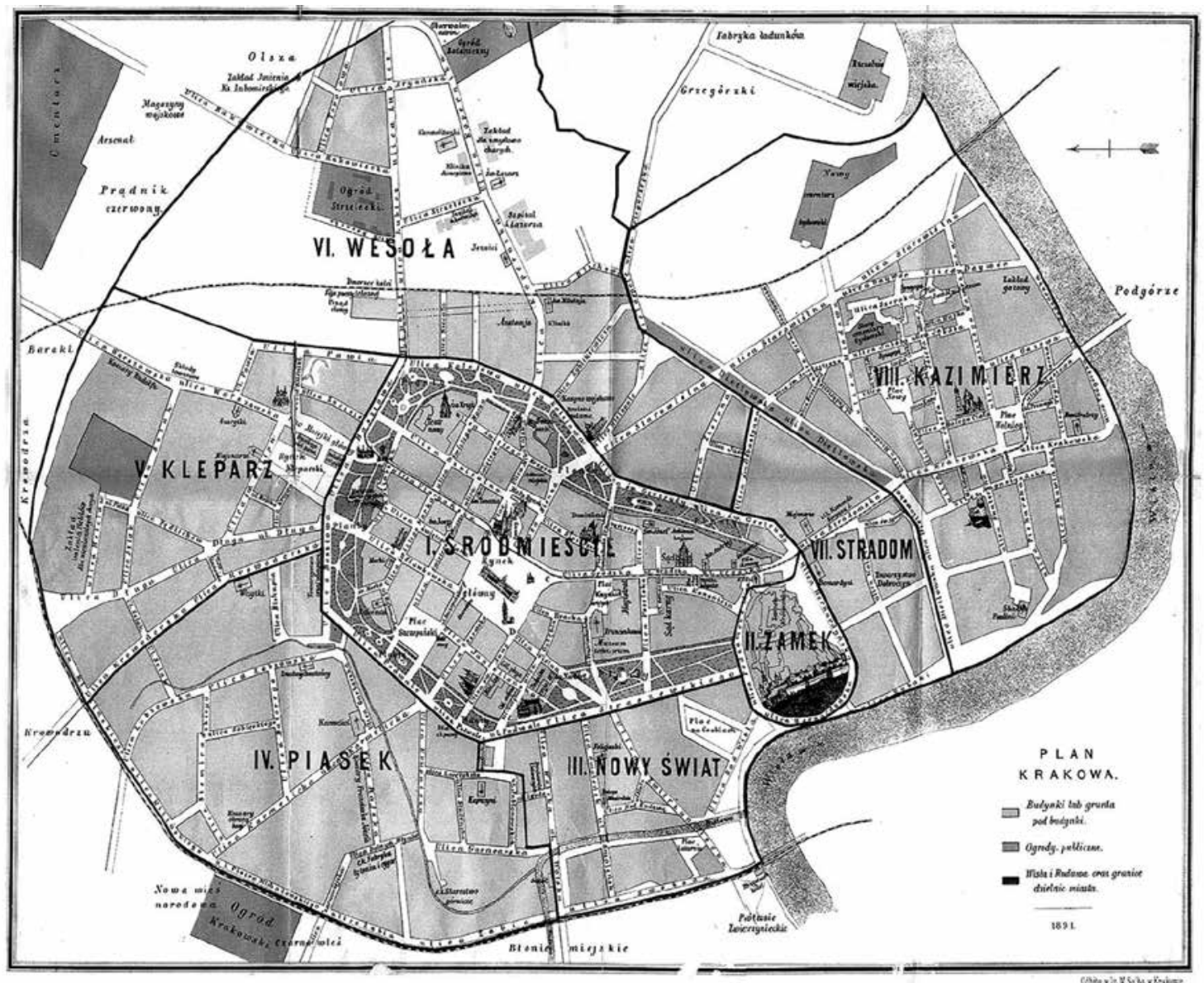

Podział administracyjny Krakowa 1859-1909 na osiem dzielnic pomocniczych. Plan miasta z 1891 r.

nad nowym ustrojem samorządowym w Polsce. Włączając się do tej debaty, opublikowałem w styczniowym numerze "Znaku” z roku 1990 artykuł pod charakterystycznym tytułem: Konstytucja dla Krakowa.

Pisałem w nim m.in.:

„Dzisiaj nie wiemy jeszcze, jaki kształt otrzyma odbudowany samorząd lokalny. Bez względu jednak na to, czy będzie to jedna, ogólna ustawa wytyczająca ramy dla różnych rodzajów samorządu terytorialnego, czy też status wielkich miast znajdzie swoje odrębne uregulowanie, nowe prawo powinno uwzględniać specyfikę i różnorodność charakteru naszych największych aglomeracji. [...]

Osobiście optuję za odrębnym uregulowaniem statusu prawnego Krakowa. Wynika to nie z lokalnego patriotyzmu, lecz raczej ze świadomości potrzeb i niewykorzystanych możliwości tego miasta. Sądzę, że punktem wyjścia
Miasto. Pamięć i Przyszłość 1 (2016) ISSN 2543-621X 


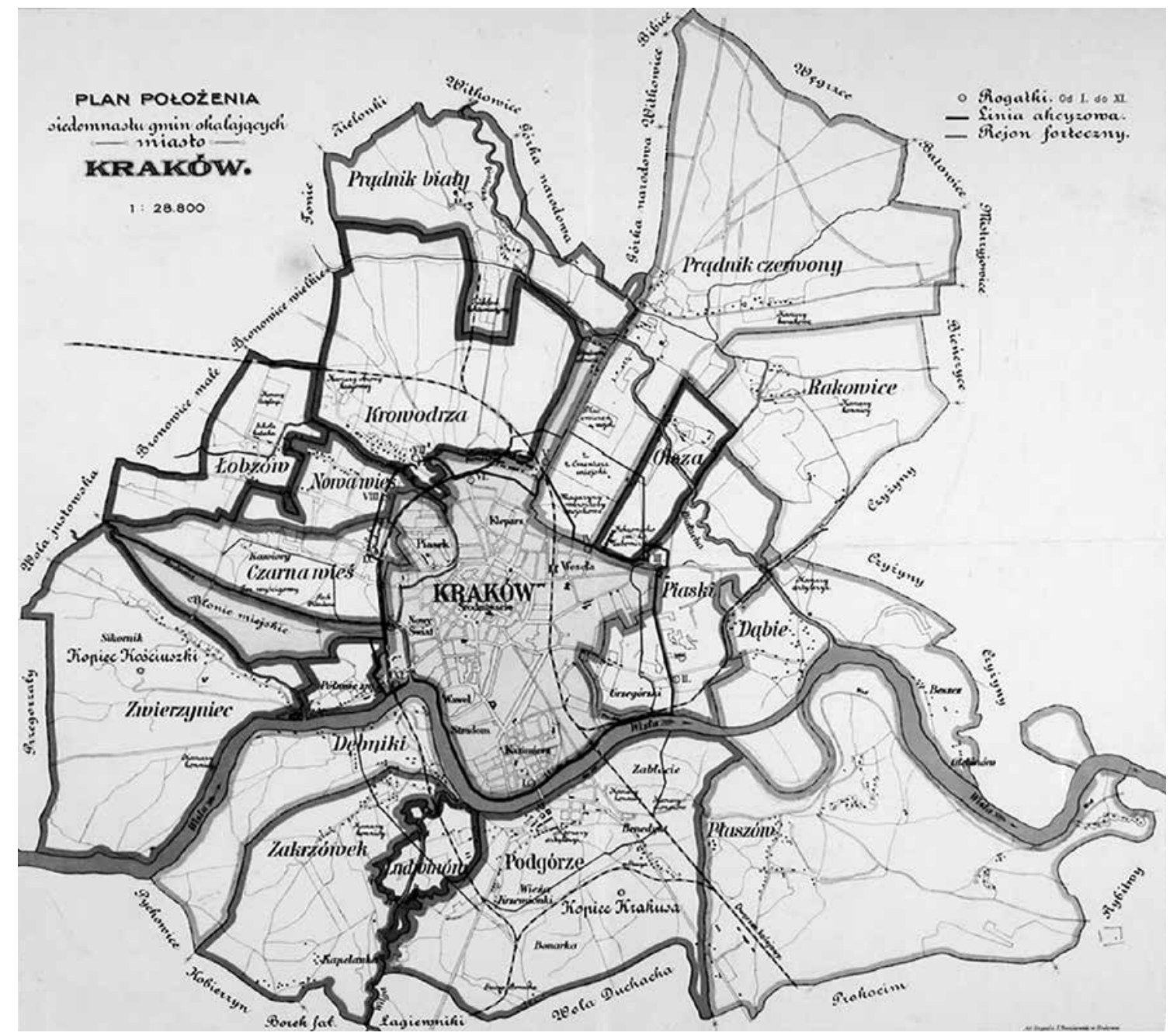

Granice administracyjne Krakowa i gmin ościennych w 1905 r.

dla poszukiwania optymalnego modelu samorządu lokalnego Krakowa stać się winien tzw. model dwusamorządowy. Skala miasta zmusza dzisiaj do zastosowania struktury wielostopniowej; w Krakowie silna władza koncentrować się powinna przede wszystkim na szczeblu ponadlokalnym, w ratuszu. Wyposażony w szerokie kompetencje prezydent powinien wraz z podległym mu magistratem posiadać możliwość prowadzenia strategicznej polityki miejskiej. Obecny podział Krakowa na cztery wielkie dzielnice o zbyt daleko idących uprawnieniach jest z wielu względów nie do utrzymania i wymaga daleko idącej decentralizacji. Miasto trzeba podzielić na 


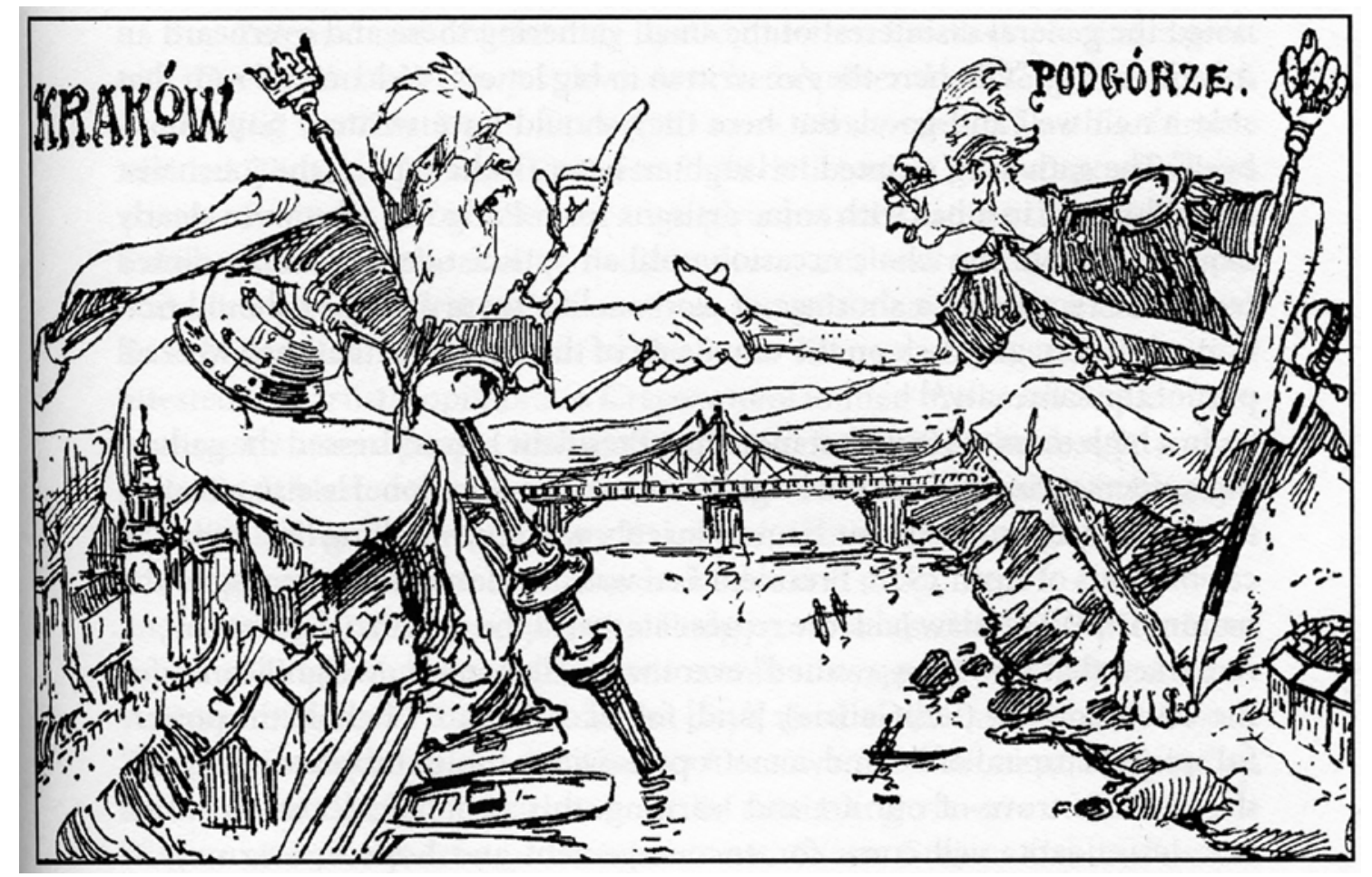

Unia Krakowa i Podgórza. Rysunek „futurystyczno-symboliczny” w "Nowinach" z 22 kwietnia 1913 r.

około 20 dzielnic, które stanowiłyby z jednej strony obwody administracji komunalnej, z drugiej zaś jednostki samorządowe szczebla lokalnego. Podział terytorialny tych jednostek oraz podział zakresu kompetencji pomiędzy oba szczeble samorządów regulowany byłby ustawowo. Jednostki stopnia podstawowego - liczące od 20 do 80 tysięcy mieszkańców - zajmowałyby się najważniejszymi sprawami miejscowych społeczności. Wytworzenie kilkunastu centrów administracyjno-usługowych i ich rozwój byłyby przy tym ważnym elementem procesu decentralizacji struktury przestrzennej i funkcjonalnej Krakowa. W obrębie takich dzielnic powinny rozwinąć Miasto. Pamięć i Przyszłość 1 (2016) ISSN 2543-621X 21 swoją aktywność komitety obywatelskie stopnia podstawowego, stanowiąc istotne ogniwo lokalnej demokracji. Taka struktura pozwoliłaby wyzwolić inicjatywę mieszkańców poszczególnych części miasta, przy zachowaniu nadrzędności interesów całego organizmu. W przypadku nowego podziału administracyjnego Krakowa należy rozważyć możliwość częściowego przynajmniej powrotu do historycznych gmin katastralnych, których granice bezmyślnie zatarto w latach siedemdziesiątych"2.

W moich ówczesnych studiach nad nowym podziałem wielkiego miasta na jednostki pomocnicze - jako przewodniczącego Komisji Statutowej

2. J. Purchla, Konstytucja dla Krakowa. Tradycja i przyszłość krakowskiego samorządu miejskiego, „Znak”, R. 42: 1990 nr 1 (416), s. 92-93. 


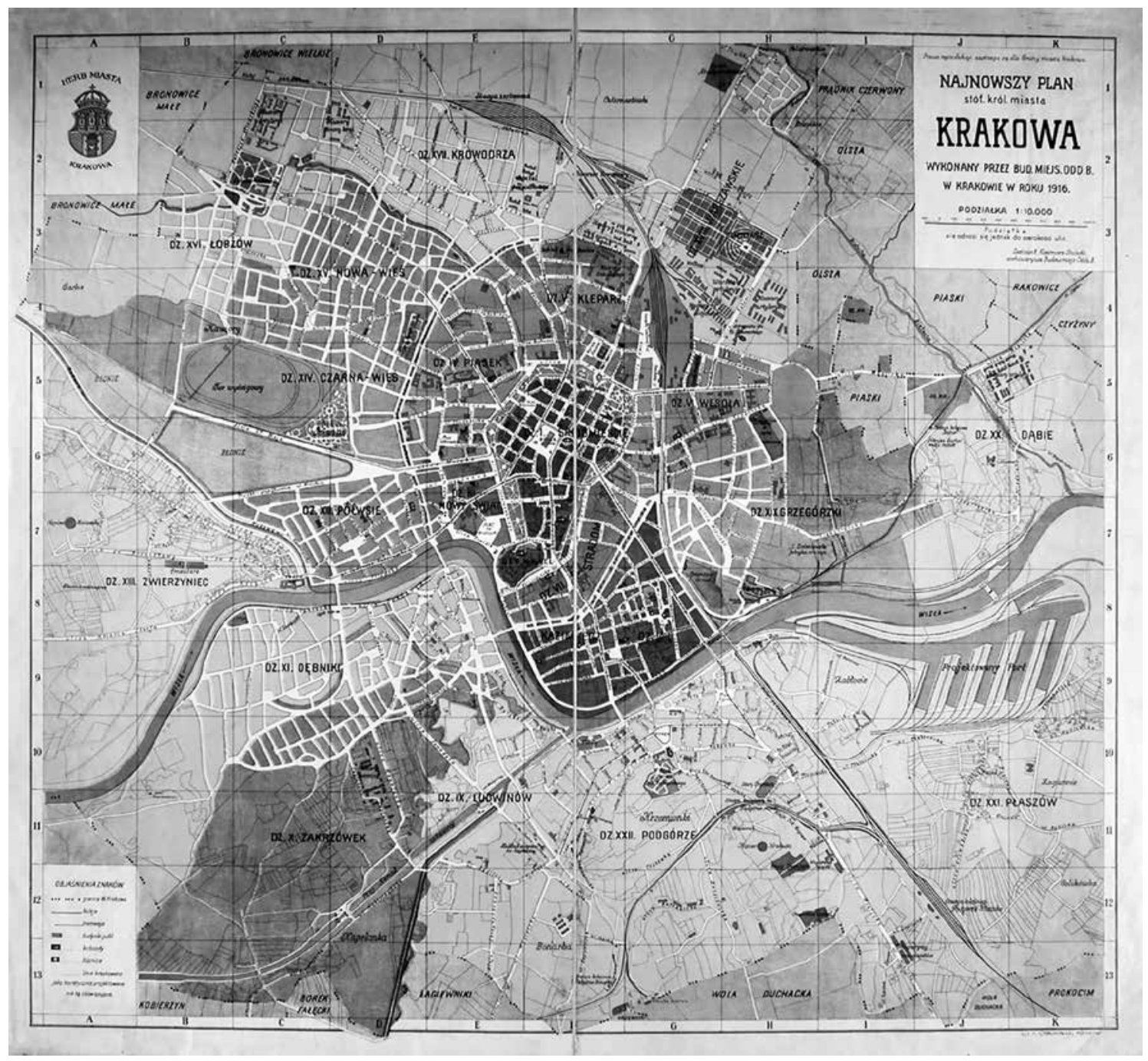

Wielki Kraków Juliusza Lea. Plan miasta z 1916 r.

Krakowskiego Komitetu Obywatelskiego "Solidarnośćc - sięgałem wprost do doświadczenia Wiednia i Grazu. Samorządy miast austriackich nieprzerwanie działały na gruncie ustawy gminnej z roku 1862, której autorem był nota bene Antoni Zygmunt Helcel, profesor prawa Uniwersytetu Jagiellońskiego ${ }^{3}$. Na tej ustawie oparty też został ustrój samorządowy Krakowa, nadany miastu w roku 1866 w formie osobnego statutu przez cesarza Franciszka Józefa I. Ten model samorządu nie tylko znakomicie sprawdził się w praktyce, ale przetrwał na terytorium byłej Galicji do roku 1950! Statuty Wiednia i Grazu - wyrastające z tego samego mianownika co krakowski z roku

3. J. Purchla, Narodziny nowoczesnego samorzadu miejskiego w Krakowie, [w:] Vademecum radnego dzielnicy, red. K. Trafas, Kraków 1996, s.118-120.

Miasto. Pamięć i Przyszłość 1 (2016) ISSN 2543-621X 


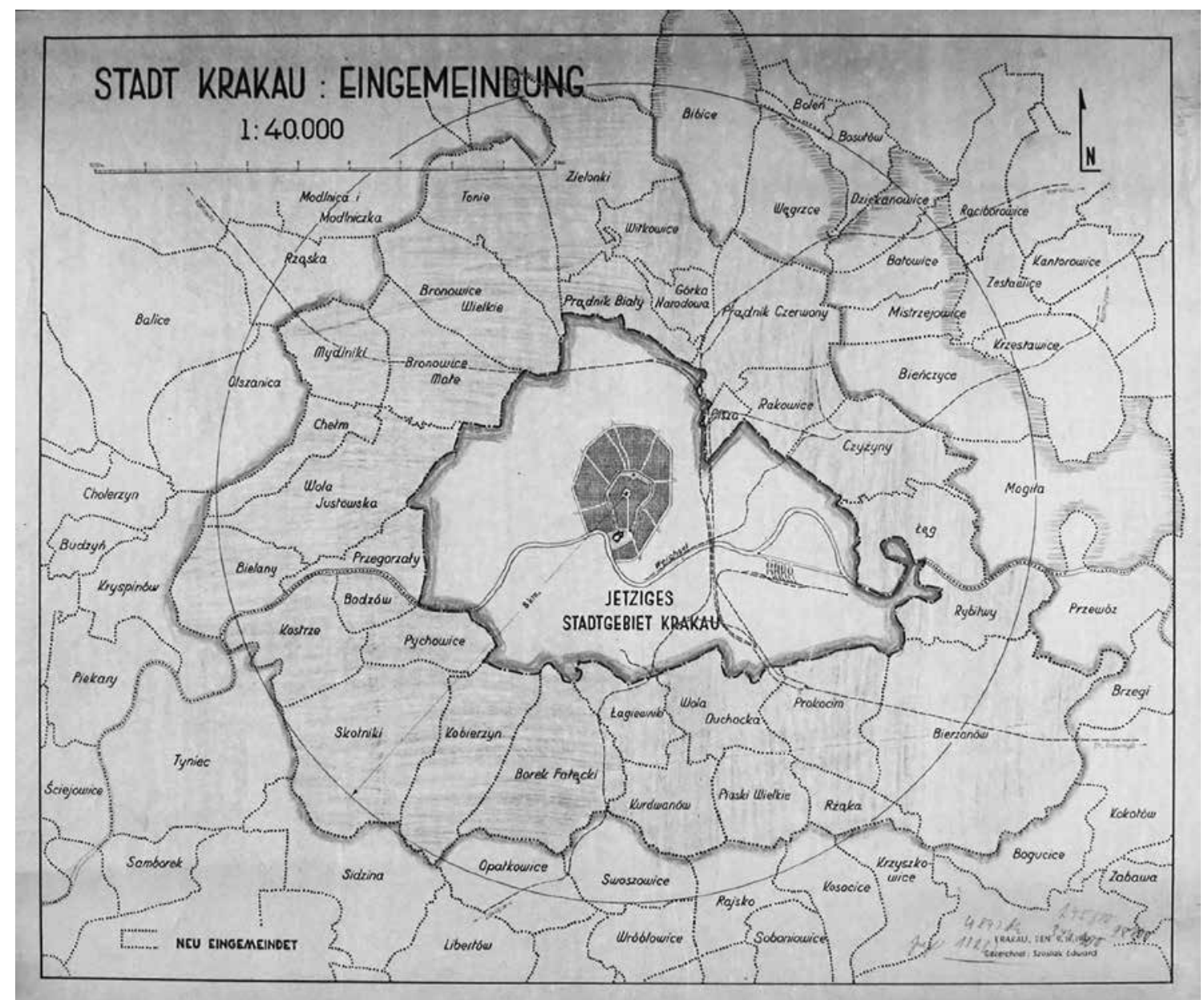

Rozszerzenie granic Krakowa z 1 czerwca 1941 r.

1866 - były więc dla mnie na przełomie roku 1989 i 1990 ważną wskazówką w kwestii kompetencji i roli dzielnic pomocniczych ${ }^{4}$. Elementem tego modelu były m.in. tzw. Bezirk - odpowiednik dzielnicy - i Bezirksamt - odpowiednik urzędu dzielnicy. Właśnie w roku 1988 decentralizacja zarządzania Wiedniem (który w federacyjnym systemie Austrii posiada dziś status odrębnego kraju związkowego) objęła wszystkie dzielnice ${ }^{5}$.

Miasto. Pamięć i Przyszłość 1 (2016) ISSN 2543-621X
Tak np. w Wiedniu 1-2\% budżetu miasta w roku 1990 oddano do dyspozycji rad Bezirków ${ }^{6}$.

Dylematy związane z nowym podziałem administracyjnym Krakowa dyskutowane były na burzliwych posiedzeniach Komitetu

4. Na wspólną genezę modelu samorządowego Austrii i Polski (terenów dawnej Galicji i Śląska Cieszyńskiego zwracano uwagę już wcześniej. Por.: Probleme der Gemeindeverwaltung in Oesterreich und Polen, hrsg. R. Walter, Wien 1982.

5. Wiener Stadt Verfassung, Wien 1988; Geschaefts Ordnung der Bezirks Vertretungen, Wien 1988; Geschaefts Ordnung fuer den Magistrat, Wien 1989.

6. R. Rutkowski, Jednostki pomocnicze w samorzadach. Model austriacki. Decentralizacja w zarządzaniu Wiedniem, [w:] Vademecum radnego dzielnicy, red. K. Trafas, Kraków 1996, s. 91-94. 
Obywatelskiego zimą i wiosną 1990 r. Komitet w tej sprawie wyraźnie się spolaryzował. Spór dotyczył losu czterech wielkich dzielnic, na które podzielono Kraków w roku 1973. Przedstawiciele Komitetów Obywatelskich z Krowodrzy i Podgórza twardo bronili koncepcji Krakowa czterech gmin, Śródmieście zaś i (co może zaskakiwać) Nowa Huta opowiadały się za likwidacją czterech dzielnic, jako czynnika dezintegrującego dalszy rozwój Krakowa. Publicznie zadawano wówczas pytanie: „jeden czy cztery Krakowy?". Ta absurdalna sytuacja wynikała w dużej mierze z ambicji liderów dzielnicowych komitetów obywatelskich. Niektórzy z nich marzyli, aby ich dzielnice zostały autonomicznymi gminami, a Kraków zaledwie ich luźną federacją. Dyskusja w sprawie podziału wewnętrznego była więc w istocie walką o kształt ustrojowy Krakowa. Podkreślałem wówczas, „że nie można oprzeć dalszego rozwoju Krakowa na totalitarnej kreacji z początku lat siedemdziesiątych". Utrzymanie czterech wielkich dzielnic blokowałoby również budowanie struktur lokalnych poprzez stworzenie dzielnic pomocniczych - małych Ojczyzn. Paradoksalnie koncepcji spetryfikowania czterech dzielnic broniło też wielu działaczy KKO "S" szczebla lokalnego. Jak bardzo idąca po władzę w mieście "Solidarność" była w tej sprawie podzielona, niech świadczy fakt, iż model samorządowy Krakowa jako jednej gminy z jednym prezydentem miasta (a nie czterema prezydentami czterech odrębnych gmin-dzielnic) został przyjęty przez Walne Zebranie delegatów KKO "S" większością zaledwie 7 głosów7. Udało nam się wówczas przesądzić o przywróceniu Krakowowi jego integralności (nie popełniając błędu Warszawy, która stała się w 1990 r. swoistą "federacją" wielu gmin). Tylko bowiem jedna, silna gmina miejska - jako fundament strategicznego rozwoju - może być skutecznym graczem z otoczeniem.

W dyskusji nad nowym podziałem administracyjnym Krakowa największą trudnością - wiosną 1990 r. - nie był jednak opór Krowodrzy i Podgórza marzących o byciu suwerennymi gminami, ale konieczność cofnięcia zegara historii! Trzeba w tym miejscu krótko przypomnieć fazy rozwoju terytorialnego Krakowa i historię różnych systemów podziału administracyjnego miasta.

Obszar administracyjny Krakowa w latach 1859-1909 obejmował zaledwie powierzchnię 5,77 km kwadratowych, podzielonych na osiem dzielnic: Śródmieście (dz. I), Wawel (dz. II), Nowy Świat (dz. III), Piasek (dz. IV), Kleparz (dz. V), Wesoła (dz. VI), Stradom (dz. VII), Kazimierz (dz. VIII). Podział miasta na kilka dzielnic katastralnych służył przede wszystkim celom podatkowym. Istniejący od roku 1866 w Krakowie samorząd gminny wykonywał swoje funkcje na stosunkowo niewielkim terytorium w sposób scentralizowany. Magistrat jako organ wykonawczy gminy posiadał na terenie 8 dzielnic jedynie 3 obwody z komisarzami obwodowymi, którzy wykonywali czynności urzędowe w zakresie bezpieczeństwa, porządku, czystości, przepisów budowlanych i ogniowych. W roku 1890 Kraków liczył niespełna 70 tysięcy mieszkańców. Już jednak od lat osiemdziesiątych XIX stulecia miał miejsce żywiołowy rozwój 16 gmin otaczających Kraków,
7. B.H. Kosior, Dzielnice miasta Krakowa. Powstanie i działalność w latach 90, Kraków 2011, rozdział 2b.

8. Encyklopedia Krakowa, red. D. Kalisiewicz, Warszawa-Kraków 2000, s. 685.
Miasto. Pamięć i Przyszłość 1 (2016) ISSN 2543-621X 
z których tylko przemysłowe Podgórze posiadało prawa miejskie. Podjęty w latach 1909-1915 przez prezydenta Krakowa Juliusza Lea plan stworzenia Wielkiego Krakowa oznaczał nie tylko przyłączenie kilkunastu gmin zewnętrznych i znaczne rozszerzenie obszaru administracyjnego miasta (z 5,77 km do 46,90 km kwadratowych), ale wymuszał potrzebę nowego podejścia do problemu zarządzania szybko rozwijającą się gminą, która po przyłączeniu w roku 1915 Podgórza liczyła 185 tys. ludności cywilnej. Dalszy rozwój miasta i jego struktury administracyjnej miał charakter addytywny. 24 jednostki katastralne o różnym stopniu urbanizacji - w tym dwa miasta - tworzyły teraz jeden organizm miejski10. Przyłączone do Krakowa gminy utraciły suwerenność i odrębne organy samorządowe, ale zachowały historyczną tożsamość. Dla usprawnienia swojej działalności na znacznie poszerzonym terytorium krakowski magistrat stworzył w latach 1910 i 1915 kolejne 2 obwody, a w latach dwudziestych zwiększył ich liczbę do 10. W roku 1938 zredukowano jednak liczbę obwodów do 6. Na ich terenie działały miejskie urzędy obwodowe dla administracyjnej obsługi mieszkańców. Sam zaś ustrój samorządowy w Krakowie pozostawał jednoszczeblowy i scentralizowany ${ }^{11}$. Trzy lata później miał miejsce najbardziej spektakularny rozrost terytorialny Krakowa w XX w. Niemieckie koncepcje przekształcania miasta w stolicę Generalnego Gubernatorstwa charakteryzowała bowiem totalitarna gigantomania. 1 czerwca 1941 r. obszar miasta został powiększony niemal czterokrotnie, do ponad 165 km kwadratowych.

Miasto. Pamięć i Przyszłość 1 (2016) ISSN 2543-621X 25
Z inicjatywy Hansa Franka do jego „stolicy” przyłączono 28 gromad i dwie gminy wiejskie, zwiększając liczbę mieszkańców Krakowa o 72 tys. do poziomu 320 tys. ${ }^{12}$. Niemcy utrzymali historyczny już podział katastralny, równocześnie zwiększając ilość urzędów obwodowych do $10^{13}$. Posiadały one rzymską numerację od I do X, "nałożoną" na sieć ponad pięćdziesięciu jednostek katastralnych znajdujących się w granicach Krakowa. Decyzja okupacyjnych władz niemieckich została po wojnie podtrzymana dopiero rozporządzeniem Rady Ministrów z 25 października 1948 r. „z mocą obowiązującą od 18 stycznia 1945"144. Ostateczna likwidacja samorządu terytorialnego w PRL na przełomie lat czterdziestych i pięćdziesiątychch - przyspieszyła demontaż dotychczasowego systemu zarządzania i likwidację istniejących jeszcze urzędów obwodowych, które ostatecznie zniknęły z mapy Krakowa w roku 1954.

A miasto rosło. W latach 1950-1990 Kraków odnotował najwyższą dynamikę wzrostu ludności wśród największych polskich metropolii. W ciągu 40 lat zwiększył liczbę mieszkańców z 344 tys. do 750 tys., czyli o 118\% ${ }^{15}$. Był to przede wszystkim skutek "socjalistycznej industrializacji", która równocześnie zmieniała strukturę społeczną miasta. Nowa Huta - pierwotnie

9. J. Purchla, Narodziny Wielkiego Krakowa, [w:] Wielki Kraków, red. J.M. Małecki, Kraków 2011, s. 9-18.

10. J. Purchla, W sprawie granic ag/omeracji miejskich, "Roczniki Dziejów Społecznych i Gospodarczych", T. 41: 1980, s. 284-286. 11. Encyklopedia Krakowa, op. cit., s. 685.

12. A. Chwalba, Dzieje Krakowa, T.5, Kraków w latach 1939-1945, Kraków 2002, s. 33.

13. R. Sady, Kraków i jego dzielnice 1945-2002, Kraków 2003, s. 130.

14. Ibidem, s.12.

15. Ibidem, s. 31-32. 


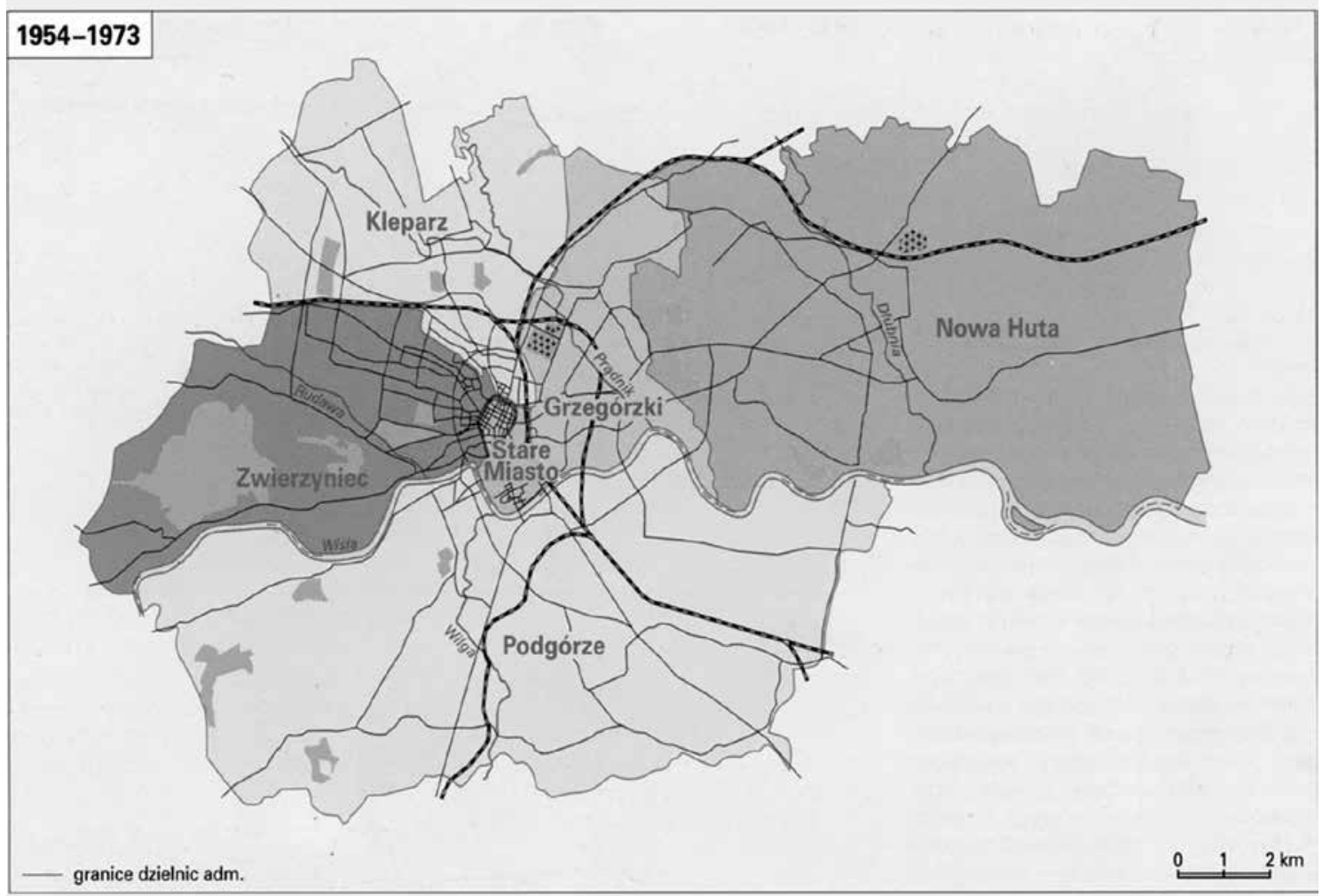

Podział administracyjny Krakowa na sześć dzielnic z roku 1954. Wg Encyklopedia Krakowa. A.H. Stachowski [red.], Warszawa-Kraków 2000.

pomyślana jako satelitarne miasto przemysłowe i odrębny organizm administracyjny już od 1 stycznia 1951 r. była dzielnicą Krakowa, zwiększając powierzchnię miasta o prawie $65 \mathrm{~km}$ kwadratowych i wchłaniając kilkanaście kolejnych jednostek katastralnych. Bipolarność stworzona przez szybko rozwijającą się Nową Hutę - jako osobną wielką dzielnicę Krakowa przesądziła też o ostatecznym podziale miasta na 6 dużych dzielnic. Operację tę przeprowadzono w roku 1954 zgodnie z uchwałami Rady Ministrów w sprawie podziału administracyjnego większych miast i zakresu działalności dzielnicowych rad narodowych ${ }^{16}$. Podział ten przetrwał następnych 18 lat. W roku 1972 liczbę wielkich dzielnic Krakowa zredukowano z 6 do 4. Były to: Śródmieście, Krowodrza, Podgórze i Nowa Huta ${ }^{17}$. Kolejnym etapem rozrostu miasta i próbą złagodzenia narastającego deficytu terenów budowlanych na jego obrzeżach było rozszerzenie 1 stycznia 1973 r. granic administracyjnych o dalsze 100,96 km kwadratowych. Przyłączono wówczas do Krakowa 22 wsie $^{18}$. Ostatnie niewielkie poszerzenie terytorium miasta przeprowadzono jeszcze w roku 1986. Tak więc zaledwie w ciągu kilku dziesięcioleci

16. Ibidem, s.131-132.

17. Ibidem, s.146.

18. R. Mydel, Rozwój struktury przestrzennej miasta Krakowa, Wrocław-Warszawa-Kraków-Gdańsk1979, s. 25.

Miasto. Pamięć i Przyszłość 1 (2016) ISSN 2543-621X 


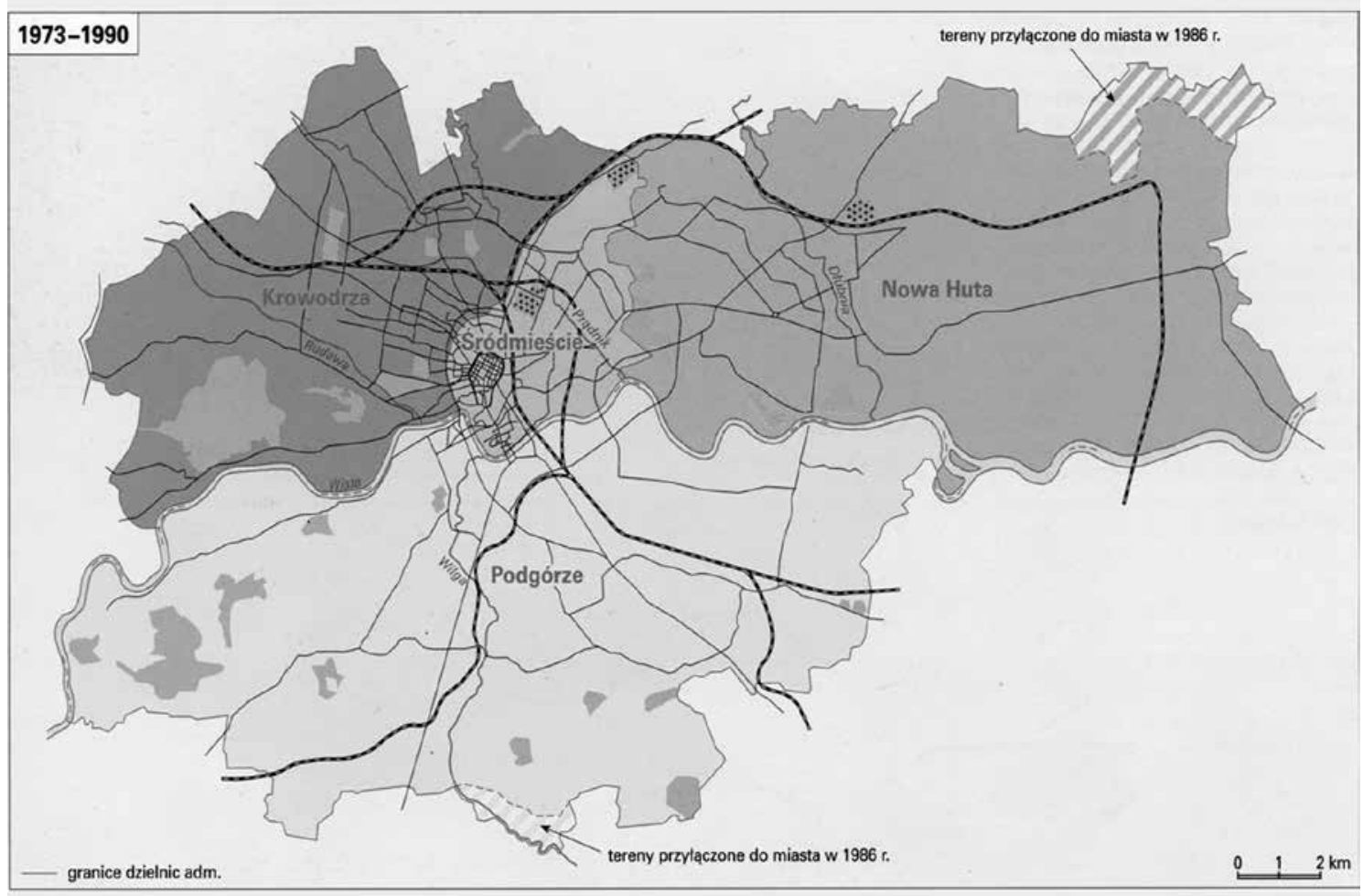

Podział administracyjny Krakowa 1972-1991. Wg Encyklopedia Krakowa. A.H. Stachowski [red.], Warszawa-Kraków 2000.

XX w. Kraków urósł terytorialnie z 5,77 km kwadratowych w roku 1909 do ponad 326,85 km kwadratowych w roku 1990.

Gwałtownemu rozrostowi ówczesnego organizmu miejskiego towarzyszyło zacieranie historycznych jednostek katastralnych i przerwanie historycznej ciągłości addytywnego rozwoju terytorialnego. W roku 1990 na terenie nowo utworzonej gminy Kraków było ich już nie 8 (jak w czasach pierwszego prezydenta Krakowa Józefa Dietla) i nie 24 (jak w czasach prezydenta Lea) ale 141!

Stanęliśmy więc przed koniecznością przyjęcia kryteriów dla agregacji tych 141 jednostek strukturalnych dla stworzenia około 20 nowych dzielnic - jako jednostek pomocniczych. Pierwsze przymiarki wykonywane wspólnie z Januszem Sepiołem doprowadziły do wytypowania 17 potencjalnych jednostek pomocniczych liczących od 20 do 65 tys. mieszkańców. Nie jest tajemnicą, że istniejące układy przestrzenne były dla nas ważniejsze niż ludnościowe. Przyjęte przez nas kryteria podziału uwzględniały:

- aktualne obwody spisowe przy przyjęciu zasady niedzielenia ich, co miało istotne znaczenie dla celów statystycznych; 


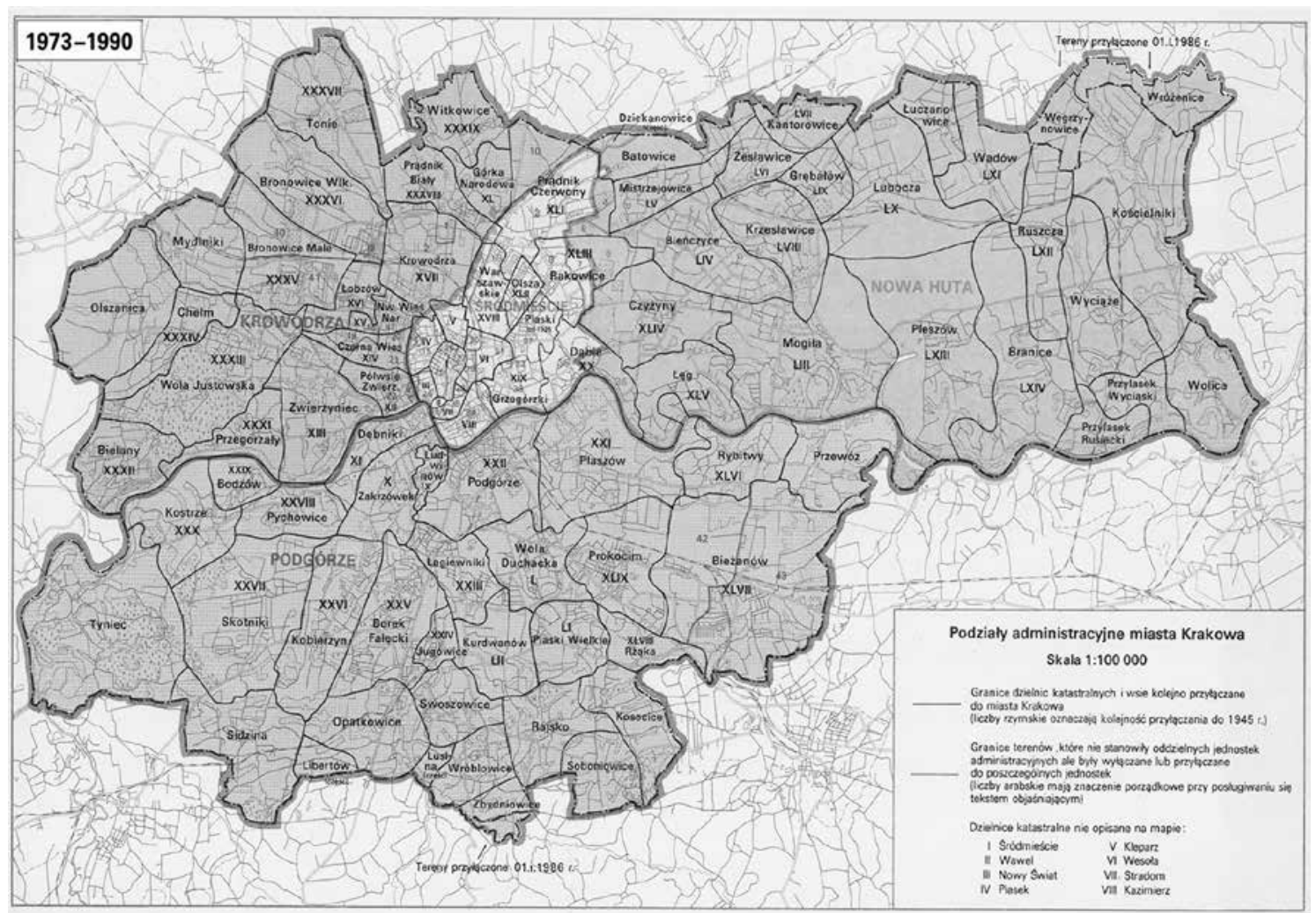

Podziały administracyjne Krakowa do roku 1990. Wg Atlas miasta Krakowa. K. Trafas [red.], Warszawa-Wrocław 1988.

- $\quad$ istniejące obwody szkolne, co w naszej opinii miało znaczenie ze względu na istniejące kontakty społeczne poprzez szkołę;

- granice komitetów osiedlowych - było to szczególnie istotne na obszarach peryferyjnych z uwagi na identyfikację społeczną z dawnym obszarem wiejskim czy osiedlem podmiejskim, do którego te granice nawiązują, a także ze względu na konieczność uwzględnienia barier przestrzennych (rzeki, linie kolejowe, główne arterie drogowe);

- granice parafii z uwagi na więzi społeczne poprzez przynależność do wspólnoty parafialnej (istotne zarówno w części centralnej miasta, jak i na jego obszarach peryferyjnych);

- historyczne granice jednostek katastralnych (dawnych gmin), zwłaszcza na obszarach, gdzie nie zostały one przekreślone wprowadzeniem nowych elementów zapewniających inną jakość spójności terytoriów lub powstaniem nowych barier (arterii drogowych, linii kolejowych);

- naturalne bariery, w tym cieki wodne i tereny otwarte oraz istniejące i przewidywane w planach bariery techniczne. 


\section{KRAKODW}

JEDNOSTKI ADMINISTRACYJNE I STRUKTURALNE

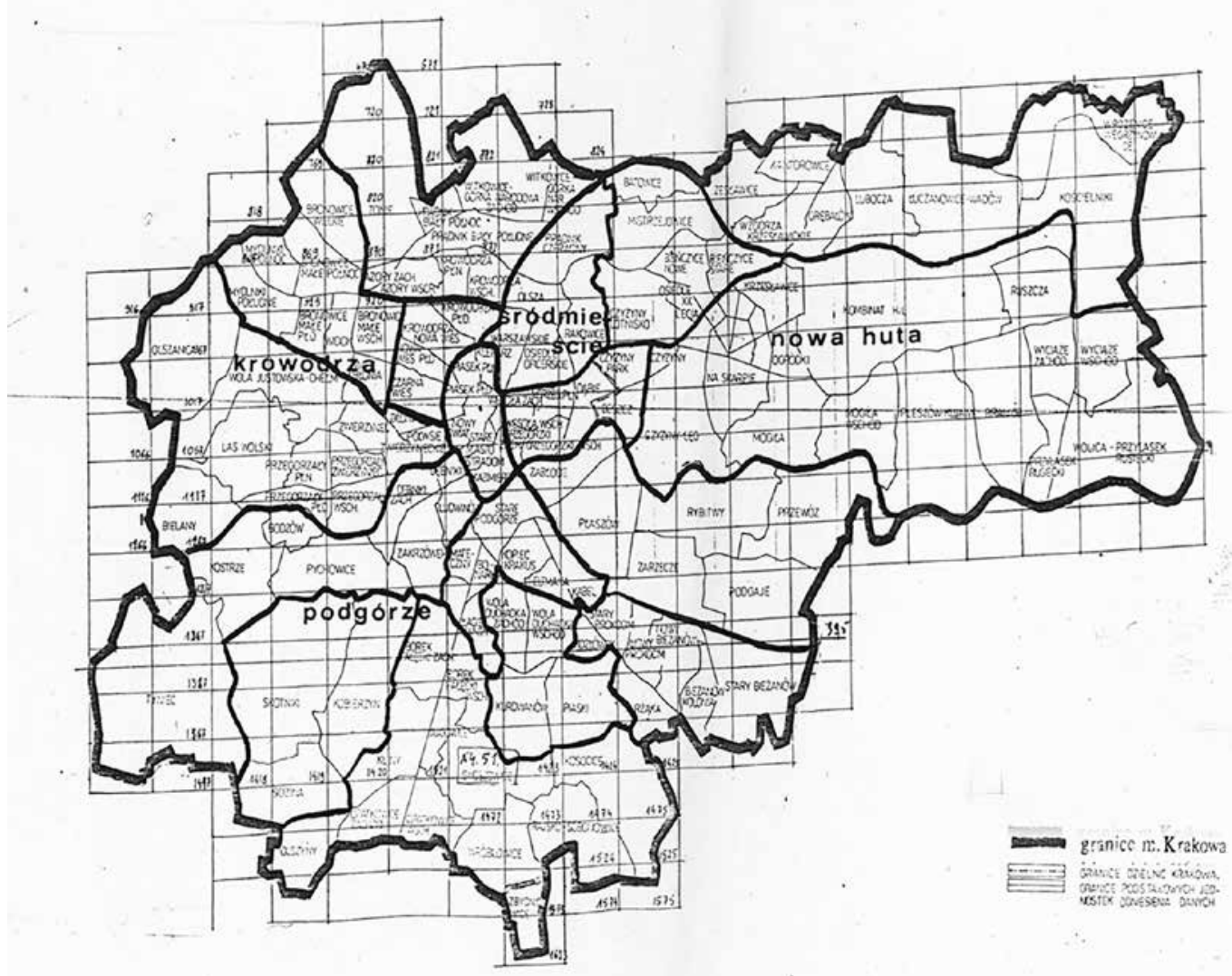

Koncepcja podziału Krakowa na 17 dzielnic pomocniczych z roku 1990.

Opracowując wstępną koncepcję, próbowaliśmy także uwzględniać wyposażenie planowanej jednostki pomocniczej w usługi ogólnomiejskie oraz istnienie głównej ulicy lub placu, skupiających handel i usługi połączonych z centrum miasta środkami komunikacji masowej ${ }^{19}$.

Miasto. Pamięć i Przyszłość 1 (2016) ISSN 2543-621X
Pracami nad przygotowaniem ostatecznej wersji projektu kierował profesor Kazimierz Trafas - geograf z Uniwersytetu Jagiellońskiego. Najpierw w ramach struktur KKO "Solidarność", a po wyborach 27 maja 1990 r. jako radny i dyrektor nowo utworzonego wydziału strategii Urzędu Miasta. Kazimierz Trafas wraz z zespołem i po

19. Propozycje terytorialnego podziału m. Krakowa, Kraków 1990 mszp. w posiadaniu autora.

20. B.H. Kosior, op. cit., rozdział 2c. 


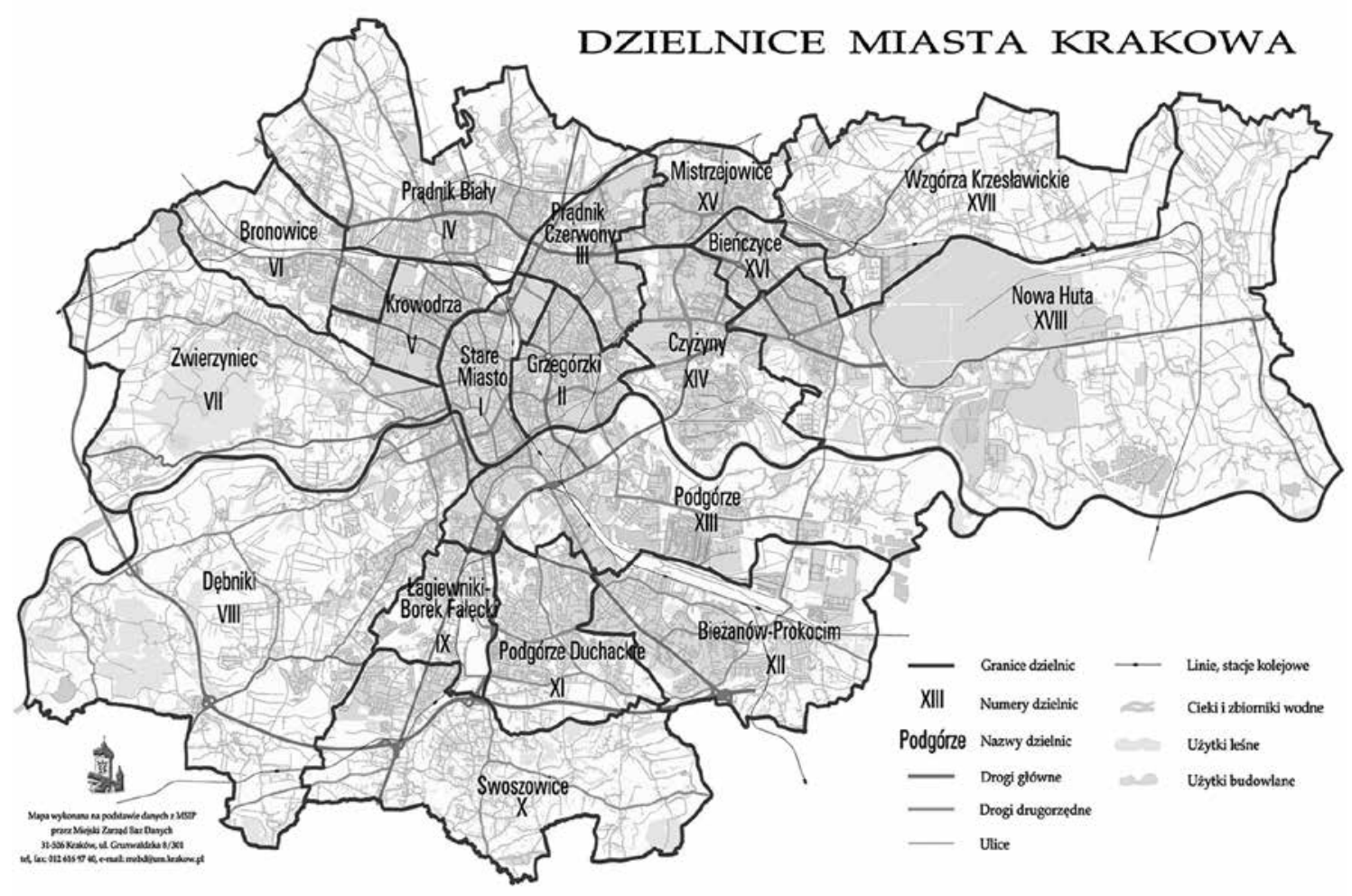

Obecny podział administracyjny gminy Kraków na 18 dzielnic pomocniczych wprowadzony w roku 1991.

przeprowadzeniu oddolnych konsultacji wypracował ostateczną wersję nowego podziału administracyjnego Krakowa na 18 dzielnic - jako jednostek pomocniczych. Powstały one w wyniku agregacji 141 jednostek katastralnych i z poszanowaniem ich historycznych granic ${ }^{20}$. Największą trudność w wykreśleniu nowych granic wewnętrznych sprawiała „parcelacja” Nowej Huty, której plan urbanistyczny został arbitralnie nałożony na terytorium kilkunastu różnych jednostek osadniczych.

27 marca 1991 r. Rada Miasta Krakowa podjęła uchwałę w sprawie utworzenia 18 dzielnic

21. Ibidem, rozdział 3a. Por. też: Uchwała Nr XXI/143/91 Rady Miasta Krakowa z dnia 27 marca 1991 w sprawie utworzenia w mieście Krakowie dzielnic miejskich.

22. J. Mikułowski-Pomorski, Idea samorządowości, [w:] Vademecum radnego dzielnicy, red. K. Trafas, Kraków 1996, s. 13. miejskich ${ }^{21}$. „Dzielnice te miały być tak pomyślane, by zachowany był związek z bezpośrednim otoczeniem mieszkańców", pisał Jerzy Mikułowski-Pomorski, trafnie konkludując, iż w ten sposób "stworzono system jednostek pośrednich między samorządem miejskim a »okolicami «"22.

Dzielnice otrzymały zarówno rzymskie numery, jak i w większości przypadków przyjęły nazwy niektórych historycznych jednostek katastralnych współtworzących poszczególne jednostki pomocnicze miasta. Rada Miasta Krakowa nadała nowo utworzonym dzielnicom odrębne, choć jednobrzmiące statuty. Zdefiniowano

Miasto. Pamięć i Przyszłość 1 (2016) ISSN 2543-621X 
w nich m.in. uprawnienia i obowiązki organów statutowych nowych dzielnic ${ }^{23}$. Rozpoczął się nie tylko nowy rozdział w historii krakowskiego samorządu, ale niemający swego końca proces tworzenia nowej dzielnicowej tożsamości.

Nasza praca nad tworzeniem koncepcji nowego podziału przypominała w roku 1990 to, co wydarzyło się w Austrii sto trzydzieści lat wcześniej w czasach Antoniego Zygmunta Helcla. Reforma dzielnicowa nie była produktem historycznej ewolucji tradycyjnych form autonomii miejskiej - bo po lekcji komunizmu być nim już nie mogła - lecz stała się racjonalistyczną kreacją legislacyjną. Towarzyszyło nam przekonanie, że próba spetryfikowania czterech wielkich dzielnic nie tylko dezintegrowała i osłabiała siłę „ratusza”, ale też ograniczała skuteczność polityki miasta w skali makro.

W roku 1990 tworzyliśmy nasz nowy urząd miejski i struktury samorządowe w biegu oraz w atmosferze ogromnych oczekiwań społecznych. Trzeba podkreślić, że rząd Tadeusza Mazowieckiego wyzwolił wielkie oczekiwania zwłaszcza wobec samorządu w wielkich miastach. Ludzie uwierzyli, że jak za dotknięciem czarodziejskiej różdżki rozwiążemy ich problemy.

Choć w roku 1990 nie mieliśmy czarodziejskiej różdżki, to przychodziliśmy do Urzędu Miasta nie tylko z najlepszymi, altruistycznymi zamiarami, ale z gotową wizją Krakowa - jednej silnej gminy i kilkunastu dzielnic pomocniczych. Jestem dziś przekonany, iż niełatwa w praktyce realizacja tej wizji okazała się bardzo trafną strategią rozwoju naszego miasta.

Miasto. Pamięć i Przyszłość 1 (2016) ISSN 2543-621X

31
Była też w skali kraju precedensem opartym na długiej tradycji samorządowej Krakowa. Fundamentami tej strategii były z jednej strony integralność gminy i siła "ratusza”, a z drugiej - podział wewnętrzny miasta wyzwalający inicjatywy obywatelskie.

Myślę dziś, iż ten system, przyjęty ostatecznie w roku 1991 przez Radę Stołecznego Królewskiego Miasta, to niewątpliwy sukces odrodzonego samorządu - strażnika dobra wspólnego. 25 lat od swego powstania nasze nowe dzielnice nie tylko osiągnęły wiek dojrzały, ale i okrzepły. Ciągle jednak ich kompetencje zdają się nieadekwatne do wyzwań, jakie zwłaszcza w wielkich miastach Polski - otwiera przed nami wielka zmiana cywilizacyjna, jaką dziś przeżywamy. Stąd i dziś spada na nas obowiązek ciągłego przypominania jakże aktualnych słów pierwszego prezydenta Józefa Dietla, który tak zagajał pierwsze posiedzenie świeżo wybranej Rady Miasta Krakowa w październiku 1866 r.:

Jacek Purchla profesor zwyczajny nauk humanistycznych; członek Polskiej Akademii Umiejętności; kieruje Katedra Historii Gospodarczej i Społecznej Uniwersytetu Ekonomicznego w Krakowie, a także Katedra Dziedzictwa Europejskiego Uniwersytetu Jagiellońskiego. Założyciel i dyrektor Międzynarodowego Centrum Kultury w Krakowie (od 1991 r.). W latach 1990-1991 wiceprezydent miasta Krakowa. Od 2015 roku Przewodniczacy Polskiego Komitetu ds. UNESCO. W 2016 r. wybrany na funkcję Przewodniczącego Komitetu Światowego Dziedzictwa UNESCO.
23. A. Karocki, Funkcjonowanie rady i zarzadu dzielnicy miejskiej w Krakowie, [w:] Vademecum radnego dzielnic, red. K. Trafas, Kraków 1996, s. 147-167. 
"Autonomia gminy to jedynie trwała podwalina państwa. To siła samorodna, żywotna, niewyczerpana, zawsze młoda i świeża. Samorząd tylko gminny, co się w następujących po sobie pokoleniach wiecznie odmładnia, stanowi niespożytą i trwałą siłę państwa"24. 


\section{Bibliografia:}

Chwalba A., Dzieje Krakowa, T.5, Kraków w latach 1939-1945, Kraków 2002.

Encyklopedia Krakowa, red. D. Kalisiewicz, Warszawa-Kraków 2000.

Karocki A., Vademecum radnego dzielnic, red. K. Trafas, Kraków 1996.

Kosior B.H., Dzielnice miasta Krakowa. Powstanie i działalność w latach 90, Kraków 2011.

Mikułowski-Pomorski J., Vademecum radnego dzielnicy, red. K. Trafas, Kraków 1996.

Mowa dra Józefa Dietla prezydenta miasta Krakowa zagajająca pierwsze posiedzenie Rady Miejskiej pod jego prezydencją dnia 31 października 1866 roku odbyte, Kraków 1866.

Mydel R., Rozwój struktury przestrzennej miasta Krakowa, Wrocław-Warszawa-Kraków-Gdańsk 1979. Probleme der Gemeindeverwaltung in Oesterreich und Polen, hrsg. R. Walter, Wien 1982. Wiener Stadt
Verfassung, Wien 1988; Geschaefts Ordnung fuer den Magistrat, Wien 1989.

Propozycje terytorialnego podziału m. Krakowa, Kraków 1990 mszp. w posiadaniu autora

Purchla J., Konstytucja dla Krakowa. Tradycja i przyszłość krakowskiego samorzadu miejskiego, "Znak”, R. 42: $1990 \mathrm{nr} 1$ (416).

Purchla J., Vademecum radnego dzielnicy, red. K. Trafas, Kraków 1996.

Purchla J., Wielki Kraków, red. J.M. Małecki, Kraków 2011.

Purchla J., W sprawie granic aglomeracji miejskich, „Roczniki Dziejów Społecznych i Gospodarczych”, T. 41: 1980.

Rutkowski R., Vademecum radnego dzielnicy, red. K. Trafas, Kraków 1996.

Sady R., Kraków i jego dzielnice 1945-2002, Kraków 2003. 